Note

\title{
Synthesis of the 6-deoxytalose-containing tetrasaccharide of the glycopeptidolipid from Mycobacterium intracellare serotype 7
}

\author{
Shiqiang Yan ${ }^{a}$, Xiaomei Liang ${ }^{a}$, Peiyu Diao ${ }^{a}$, Ye. Yang ${ }^{a}$, Jianjun Zhang ${ }^{a}, *$ Daoquan Wang ${ }^{a}$, Fanzuo Kong ${ }^{b}$ \\ ${ }^{a}$ Key Lab of Pesticide Chemistry and Application Technology, Department of Applied Chemistry, China Agricultural University, Beijing 100094, China \\ ${ }^{\mathrm{b}}$ Research Center for Eco-Environmental Sciences, Academia Sinica, PO Box 2871, Beijing 100085, China
}

\section{A R T I C L E I N F O}

\section{Article history:}

Received 10 July 2008

Received in revised form 4 September 2008

Accepted 15 September 2008

Available online 20 September 2008

\section{Keywords:}

Rhamnose

6-Deoxy- $\alpha$-L-talose

Tetrasaccharide

Selective acylation

\begin{abstract}
A B S T R A C T
An efficient synthesis of 4 -methoxyphenyl $\alpha$-L-Rhap-( $1 \rightarrow 3)-\alpha$-L-Rhap-( $1 \rightarrow 3)-\alpha$-L-Rhap-( $1 \rightarrow 2)$-6-deoxy$\alpha-\mathrm{L}-\mathrm{Tal} p$, the tetrasaccharide related to the GPLs of Mycobacterium intracellare serotype 7 , was achieved with 4-methoxyphenyl 3,4-di-O-benzoyl-6-deoxy- $\alpha$-L-talopyranoside $(\mathbf{6 c})$ as the key intermediate which was obtained through selective 3-O-benzoylation of 4-O-benzoyl-6-deoxy- $\alpha$-L-taloside. Coupling of $\mathbf{6 c}$ with 3-O-allyloxycarbonyl-2,4-di-O-benzoyl- $\alpha$-L-rhamnopyranosyl trichloroacetimidate followed by removal of the allyloxycarbonyl protecting group afforded the disaccharide acceptor 11. Condensation of 11 with 2,3,4-tri-O-benzoyl- $\alpha$-L-rhamnopyranosyl-(1 $\rightarrow 3$ )-2,4-di-O-benzoyl- $\alpha$-L-rhamnopyranosyl trichloroacetimidate and subsequent deprotection gave the target tetrasaccharide.
\end{abstract}

( 2008 Elsevier Ltd. All rights reserved.
6-Deoxy-L-talose is a key building block of many biologically important glycopeptidolipids (GPLs) ${ }^{1-4}$ and is an essential component of numerous antigenic bacterial lipopolysaccharides (LPSs) ${ }^{5-9}$ Structural analysis revealed that most of these GPLs or LPSs possess the 6-deoxy-L-talose unit in which 0-2 or 0-3 is glycosylated with other sugar units. Recently, it was proposed that the oligosaccharide part of Mycobacterium intracellare serotype 7 GPLs contains a pentasaccharide, which is composed of one 6-deoxy-L-talose, three L-rhamnoses, and one terminal amido sugar unit, while the configuration of the terminal amido sugar remained undetermined (I, Chart 1). ${ }^{10}$

M. intracellulare is distributed ubiquitously in nature and is an important cause of respiratory and lymphatic disease in human and animals. ${ }^{11}$ Since carbohydrates play an important role in bacterial physiology and pathogenesis, preparation of these GPL oligosaccharides is of considerable interest for structure-bioactivity studies of carbohydrates. ${ }^{12-15}$ In this paper, we wish to report the efficient synthesis of the well-defined tetrasaccharide II (Chart 1 ) related to the GPLs of $M$. intracellare serotype 7.

For the synthesis of the tetrasaccharide, 4-methoxyphenyl 6deoxy- $\alpha$-L-talopyranoside acceptors $(\mathbf{6 a - f}, 7 \mathbf{a}-\mathbf{d})$ with the C-2 hydroxyl free were prepared through the regioselective acylation of 6 -deoxy- $\alpha$-L-taloside 2,3 -diols (4, or $\mathbf{5})$ with acyl chlorides. As outlined in Scheme 1, 4-methoxyphenyl 2,3-O-isopropylidene- $\alpha$-Lrhamnopyranoside (1), obtained by a reported method from rhamnose, ${ }^{16}$ was oxidized with PDC $^{17}$ to afford the corresponding

\footnotetext{
* Corresponding author. Tel.: +86 10 62731115; fax: +86 1062732219 .

E-mail address: zhangjianjun@cau.edu.cn (J. Zhang).
}

glycos-4-ulose derivative $\mathbf{2}$ in 93\% yield. Reduction of $\mathbf{2}$ with sodium borohydride gave 4-methoxyphenyl 6-deoxy-2,3-0-isopropylidene- $\alpha$-L-talopyranoside (3) as crystals in $85 \%$ yield. The Tal-configuration of $\mathbf{3}$ was assigned from its ${ }^{1} \mathrm{H}$ NMR spectrum, showing characteristic signals at $\delta 3.63 \mathrm{ppm}\left(\mathrm{dd}, J_{3,4}=J_{4,5} 5.1 \mathrm{~Hz}\right.$ ) for $\mathrm{H}-4 .{ }^{14}$ Compared to the previously reported synthesis of methyl or benzyl deoxytalosides, ${ }^{18-20}$ the main advantage for the synthesis of the $p \mathrm{MP}$ glycoside in the present work was that the $p \mathrm{MP}$ taloside could be purified by crystallization, avoiding the tedious column chromatography purification step. Acylation of $\mathbf{3}$ with benzoyl chloride or pivaloyl chloride in pyridine followed by deisopropylidenation provided the 2,3 -diol $\mathbf{4}(92 \%)$ or $\mathbf{5}(76 \%)$, respectively. Compounds $\mathbf{4}$ and $\mathbf{5}$ were employed for the selective acylation reactions. Because the equatorially oriented $3-\mathrm{OH}$ is more reactive than the axial $2-\mathrm{OH}$, it was anticipated that the $3-\mathrm{OH}$ could be selectively acylated. As a typical example, $\mathbf{4}$ was treated with acetyl chloride in dichloromethane at $-10^{\circ} \mathrm{C}$ in the presence of 4 equiv of pyridine and catalytic amounts of DMAP, resulting in the 3-O-acetyl derivative (6a) in excellent yield (93\%). Other acylation reagents such as allyloxycarbonyl chloride, benzoyl chloride, chloroacetyl chloride, phenylacetyl chloride, and pivaloyl chloride were also investigated for the regioselective esterification, and in all cases the 3-OH acylated products $\mathbf{6 b - f}$ and $7 \mathbf{a}-\mathbf{d}$ were obtained in high yield (80-95\%). Low temperature and slow addition of the chlorides were necessary for optimal regioselectivity. The regioselectivity of the process was established by ${ }^{1} \mathrm{H}$ NMR spectroscopy, and the characteristic $\mathrm{H}-3$ signal was found to move to downfield upon acylation $\left(\delta_{\mathrm{H}-3} 4.33 \mathrm{ppm}\right.$ in $\mathbf{4}$ as compared to $\delta_{\mathrm{H}-3} 5.49 \mathrm{ppm}$ in $\mathbf{6 a}$ ). Further confirmation was supported by the 


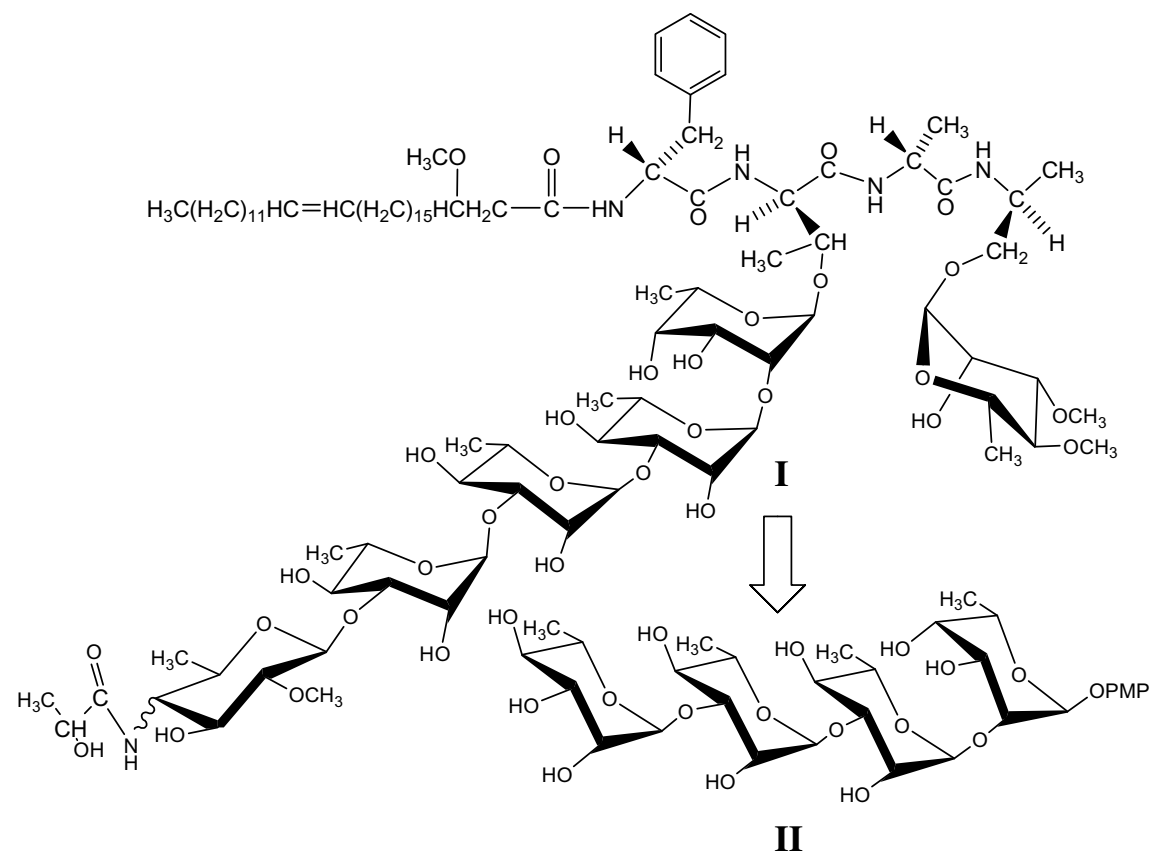

Chart 1. Proposed structure of the M. intracellare serotype 7 GPL I and the target tetrasaccharide II.

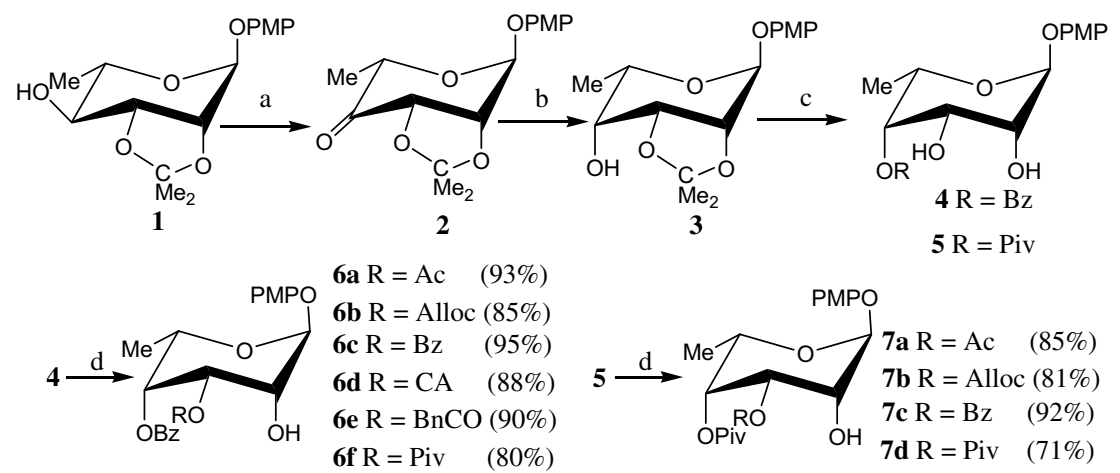

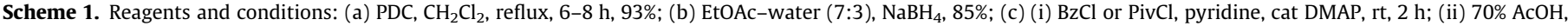
$75{ }^{\circ} \mathrm{C}, 2 \mathrm{~h}, 92 \%$ for 4 ; $76 \%$ for 5; (d) acyl chloride-pyridine, cat DMAP, $\mathrm{CH}_{2} \mathrm{Cl}_{2}$, rt.

single-crystal X-ray analysis of 4-methoxyphenyl 3-O-allyloxycarbonyl-2,4-di-O-benzoyl-6-deoxy- $\alpha$-L-talopyranoside (14), obtained from benzoylation of compound $\mathbf{6 b}$ (preparation of 14 and its X-ray data are included in the Supplementary data).

With the 6-deoxytaloside acceptors possessing a free $2-\mathrm{OH}$ at hand, synthesis of the target tetrasaccharide was readily achieved as shown in Scheme 2. In the synthesis, 4-methoxyphenyl 3-Oallyloxycarbonyl-2,4-di-O-benzoyl- $\alpha$-L-rhamnopyranoside (8) and the disaccharide donor 2,3,4-tri-O-benzoyl- $\alpha$-L-rhamnopyranosyl$(1 \rightarrow 3)-2,4$-di-O-benzoyl- $\alpha$-L-rhamnopyranosyl trichloroacetimidate (12) were prepared from L-rhamnose according to the previously reported procedures. ${ }^{21,22}$ Cleavage of the 4-methoxyphenyl group of $\mathbf{8}$ with ceric ammonium nitrate (CAN), followed by trichloroacetimidation, provided $\mathbf{9}$. Then, condensation of the donor 9 with 4-methoxyphenyl 3,4-di-O-benzoyl-6-deoxy- $\alpha$-L-talopyranoside (6c) in the presence of TMSOTf ${ }^{23}$ afforded the disaccharide $\mathbf{1 0}$, and subsequent de-allyloxycarbonylation of $\mathbf{1 0}$ with palladium catalyst ( $\mathrm{Pd}\left[\mathrm{P}\left(\mathrm{C}_{6} \mathrm{H}_{5}\right)_{3}\right]_{4}, 0.05$ equiv), $\mathrm{P}\left(\mathrm{C}_{6} \mathrm{H}_{5}\right)_{3}$ (0.3 equiv), and $\mathrm{Et}_{3} \mathrm{~N}$ (2 equiv) in $\mathrm{THF}^{24}$ gave the disaccharide acceptor $\mathbf{1 1}$ in satisfactory yield. TMSOTf-catalyzed coupling reaction of the acceptor $\mathbf{1 1}$ with the donor 12 provided the tetrasaccharide 13 in $76 \%$ yield. The ${ }^{1} \mathrm{H}$ NMR spectrum of 13 showed a doublet at $\delta 5.75 \mathrm{ppm}(J 1.2 \mathrm{~Hz})$ for
$\mathrm{H}-1$ of $\alpha$-Tal along with three doublets at $\delta 5.29 \mathrm{ppm}(J 1.8 \mathrm{~Hz}), \delta$ $4.84 \mathrm{ppm}(J 1.2 \mathrm{~Hz})$, and $\delta 4.69 \mathrm{ppm}(J 0.6 \mathrm{~Hz})$ for the three $\alpha$-Rha anomeric protons, respectively. The ${ }^{13} \mathrm{C}$ NMR spectrum showed peaks at $\delta 99.8,99.0,99.0$, and 98.6 for the four anomeric carbons. Finally deacylation of $\mathbf{1 3}$ in ammonium-saturated methanol gave the target tetrasaccharide II (Chart 1).

In conclusion, we have explored the highly selective acylation at 0-3 of 6-deoxy- $\alpha$-L-taloside 2,3-diols with acyl chloride and pyridine as mild esterification reagents, and a 6 -deoxy- $\alpha$-L-talopyranose-containing tetrasaccharide from the GPLs of $M$. intracellare serotype 7 was efficiently synthesized.

\section{Experimental}

\subsection{General methods}

Optical rotations were determined with a Perkin-Elmer model 241-MC automatic polarimeter for solns in a 1-dm jacketed cell. ${ }^{1} \mathrm{H}$ and ${ }^{13} \mathrm{C}$ NMR spectra were recorded with Bruker DPX300 and Bruker AVANCE600 spectrometers in $\mathrm{CDCl}_{3}$ or $\mathrm{D}_{2} \mathrm{O}$ solns. Internal references: TMS $\left(\delta 0.000 \mathrm{ppm}\right.$ for $\left.{ }^{1} \mathrm{H}\right), \mathrm{CDCl}_{3}(\delta 77.00 \mathrm{ppm}$ for $\left.{ }^{13} \mathrm{C}\right)$, and HOD ( $\delta 4.700$ for $\left.{ }^{1} \mathrm{H}\right) .{ }^{1} \mathrm{H}$ NMR signals of some compounds 


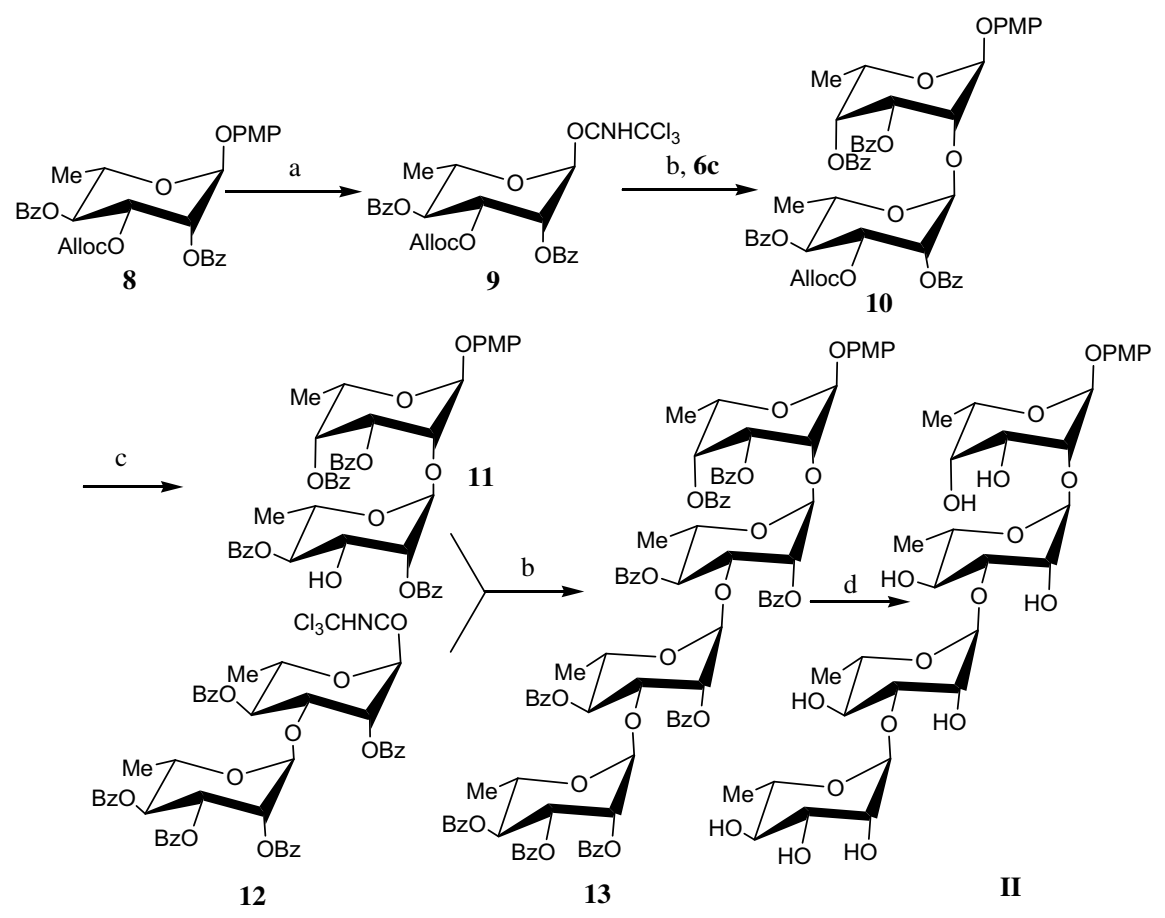

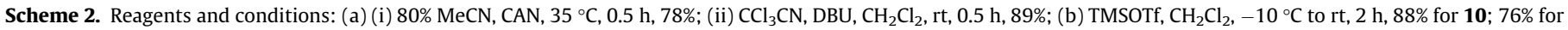
13; (c) $\mathrm{Pd}\left[\mathrm{P}\left(\mathrm{C}_{6} \mathrm{H}_{5}\right)_{3}\right]_{4}, \mathrm{P}\left(\mathrm{C}_{6} \mathrm{H}_{5}\right)_{3}, \mathrm{Et}_{3} \mathrm{~N}$, THF, rt, 81\%; (d) satd $\mathrm{NH}_{3}-\mathrm{MeOH}, \mathrm{rt}, 96 \mathrm{~h}, 91 \%$.

were assigned with the aid of COSY. Elemental analysis was performed on a Yanaco CHN Corder MF-3 automatic elemental analyzer. MALDI and ESI mass spectra were performed by the Institute of Chemistry of the Chinese Academy of Sciences. Thinlayer chromatography (TLC) was performed on Silica Gel HF with detection by charring with $30 \%(\mathrm{v} / \mathrm{v}) \mathrm{H}_{2} \mathrm{SO}_{4}$ in $\mathrm{MeOH}$ or by UV detection. Column chromatography was conducted by elution of a column of silica gel (200-300 mesh) with EtOAc-petroleum ether (bp $60-90^{\circ} \mathrm{C}$ ) as the eluent. Solns were concentrated at a temperature $<60^{\circ} \mathrm{C}$ under diminished pressure.

\subsection{4-Methoxyphenyl 6-deoxy-2,3-0-isopropylidene- $\alpha$-L-lyxo- hexopyranosid-4-ulose (2)}

A mixture of 4-methoxyphenyl 2,3-O-isopropylidene- $\alpha$-Lrhamnopyranoside $(\mathbf{1})^{16}(31.0 \mathrm{~g}, 0.1 \mathrm{~mol}), \operatorname{PDC}(23.0 \mathrm{~g}, 0.06 \mathrm{~mol})$, and acetic anhydride $(28.4 \mathrm{~mL}, 0.3 \mathrm{~mol})$ in $\mathrm{CH}_{2} \mathrm{Cl}_{2}(200 \mathrm{~mL})$ was stirred at reflux for $8 \mathrm{~h}$, at the end of which time TLC (4:1 petroleum ether-EtOAc) indicated that the reaction was complete. After direct concentration of the reaction mixture, the dark brown residue was diluted with EtOAc $(60 \mathrm{~mL})$ and the soln was passed through a short $(5-10 \mathrm{~cm})$ silica-gel column. The column was eluted with EtOAc and the eluents were concentrated and coevaporated with toluene. The residue was subjected to silica-gel column chromatography again (4:1 petroleum ether-EtOAc) to give $2(28.6 \mathrm{~g}, 93 \%)$ as a syrup; $[\alpha]_{\mathrm{D}}^{25}-90.1$ (c $\left.0.5 \mathrm{CHCl}_{3}\right) ;{ }^{1} \mathrm{H} \mathrm{NMR}$ $\left(300 \mathrm{MHz}, \mathrm{CDCl}_{3}\right): \delta 1.38$ (d, $\left.J_{5,6} 6.8 \mathrm{~Hz}, 3 \mathrm{H}, \mathrm{H}-6\right), 1.41,1.54(2 \mathrm{~s}$, $6 \mathrm{H}, \mathrm{CMe}_{2}$ ), 3.78 (s, 3H, OMe), 4.30 (q, J5,6 $\left.6.8 \mathrm{~Hz}, 1 \mathrm{H}, \mathrm{H}-5\right), 4.55-$ 4.65 (m, 2H, H-2, H-3), 5.59 (s, 1H, H-1), 6.84 (m, 2H, Ar-H), 7.00 $(\mathrm{m}, 2 \mathrm{H}, \mathrm{Ar}-\mathrm{H})$. Anal. Calcd for $\mathrm{C}_{16} \mathrm{H}_{20} \mathrm{O}_{6}: \mathrm{C}, 62.33 ; \mathrm{H}, 6.54$. Found: C, 62.09; H, 6.86 .

\subsection{4-Methoxyphenyl 6-deoxy-2,3-0-isopropylidene- $\alpha$-L- talopyranoside (3)}

To a soln of $2(15.4 \mathrm{~g}, 0.05 \mathrm{~mol})$ in 7:3 EtOAc-water $(150 \mathrm{~mL})$ at $0{ }^{\circ} \mathrm{C}$ was added $\mathrm{NaBH}_{4}(2.1 \mathrm{~g}, 0.055 \mathrm{~mol})$. The mixture was stirred at $0{ }^{\circ} \mathrm{C}$ for $15 \mathrm{~min}$, and TLC (4:1 petroleum ether-EtOAC) indicated that the reaction was complete. The aq soln was extracted with EtOAc $(3 \times 200 \mathrm{~mL})$, the extract was washed with $\mathrm{M} \mathrm{HCl}$ and satd aq $\mathrm{NaHCO}_{3}$, dried $\left(\mathrm{Na}_{2} \mathrm{SO}_{4}\right)$, and concentrated to give crude 3 as a syrup. Purification of the crude product by crystallization $(4: 1$ petroleum ether-EtOAc) provided $3(13.2 \mathrm{~g}, 85 \%)$ as white crystals (mp 93-94 ${ }^{\circ} \mathrm{C}$ ); $[\alpha]_{\mathrm{D}}^{25}-75.0$ (c $1.0 \mathrm{CHCl}_{3}$ ); ${ }^{1} \mathrm{H}$ NMR $(300 \mathrm{MHz}$, $\left.\mathrm{CDCl}_{3}\right): \delta 1.29\left(\mathrm{~d}, J_{5,6} 6.6 \mathrm{~Hz}, 3 \mathrm{H}, \mathrm{CH}_{3}\right), 1.42,1.61\left(2 \mathrm{~s}, 6 \mathrm{H}, \mathrm{CMe}_{2}\right)$, $2.32\left(\mathrm{~d}, 1 \mathrm{H}, \mathrm{OH}\right.$, exchangeable with $\left.\mathrm{D}_{2} \mathrm{O}\right), 3.63$ (dd, $\left.J_{3,4}=J_{4,5}=5.1 \mathrm{~Hz}, 1 \mathrm{H}, \mathrm{H}-4\right), 3.76(\mathrm{~s}, 3 \mathrm{H}, \mathrm{OMe}), 4.00(\mathrm{~m}, 1 \mathrm{H}, \mathrm{H}-5)$, 4.27 (dd, $\left.J_{1,2} 0.8 \mathrm{~Hz}, J_{2,3} 6.4 \mathrm{~Hz}, 1 \mathrm{H}, \mathrm{H}-2\right), 4.36$ (d, $J_{2,3} 6.4 \mathrm{~Hz}, J_{3,4}$ $5.1 \mathrm{~Hz}, 1 \mathrm{H}, \mathrm{H}-3), 5.66(\mathrm{~s}, 1 \mathrm{H}, \mathrm{H}-1), 6.84(\mathrm{~m}, 2 \mathrm{H}, \operatorname{Ar}-H), 7.00(\mathrm{~m}$, $2 \mathrm{H}, \mathrm{Ar}-\mathrm{H}$ ). Anal. Calcd for $\mathrm{C}_{16} \mathrm{H}_{22} \mathrm{O}_{6}$ : C, 61.92; H, 7.15. Found: $\mathrm{C}$, $62.11 ; \mathrm{H}, 7.02$.

\subsection{4-Methoxyphenyl 4-0-benzoyl-6-deoxy- $\alpha$-L-talopyranoside} (4)

To a soln of 3 ( $12.4 \mathrm{~g}, 0.04 \mathrm{~mol})$ in pyridine $(60 \mathrm{~mL})$ was added benzoyl chloride $(5.6 \mathrm{~mL}, 0.048 \mathrm{~mol})$ dropwise. After stirring for $8 \mathrm{~h}$ at rt, TLC ( $3: 1$ petroleum ether-EtOAc) indicated that the reaction was complete. $\mathrm{MeOH}(1 \mathrm{~mL})$ was added to quench the reaction and then water $(100 \mathrm{~mL})$ was added to the reaction mixture. The aq soln was extracted with EtOAc $(3 \times 200 \mathrm{~mL})$, the extract was washed with $\mathrm{M} \mathrm{HCl}$ and satd aq sodium hydrogencarbonate, dried $\left(\mathrm{Na}_{2} \mathrm{SO}_{4}\right)$, and concentrated. The residue was dissolved in $70 \%$ $\mathrm{AcOH}(200 \mathrm{~mL})$ and stirred for $3 \mathrm{~h}$ at $75^{\circ} \mathrm{C}$, at the end of which time TLC (2:1 petroleum ether-EtOAc) indicated completion of the reaction. The mixture was concentrated under diminished pressure and then coevaporated with toluene $(2 \times 40 \mathrm{~mL})$. The residue was passed through a short silica-gel column with 5:2 petroleum ether-EtOAc as the eluent to give 4 ( $13.8 \mathrm{~g}, 92 \%$ for two steps) as a foamy solid; $[\alpha]_{\mathrm{D}}^{25}+48.0\left(\right.$ c $\left.0.5 \mathrm{CHCl}_{3}\right) ;{ }^{1} \mathrm{H} \mathrm{NMR}\left(600 \mathrm{MHz}, \mathrm{CDCl}_{3}\right)$ : $\delta 1.22$ (d, J5,6 $6.6 \mathrm{~Hz}, 3 \mathrm{H}, \mathrm{CH}_{3}$ ), 2.65 (br s, $\left.2 \mathrm{H}, 2 \mathrm{OH}\right), 3.82(\mathrm{~s}, 3 \mathrm{H}$, OMe), 4.03 (dd, $J_{1,2} 1.8 \mathrm{~Hz}, J_{2,3} 3.6 \mathrm{~Hz}, 1 \mathrm{H}, \mathrm{H}-2$ ), 4.30 (q, $J_{5,6}$ $6.6 \mathrm{~Hz}, 1 \mathrm{H}, \mathrm{H}-5$ ), 4.33 (dd, $J_{2,3}=J_{3,4}=3.6 \mathrm{~Hz}, 1 \mathrm{H}, \mathrm{H}-3$ ), 5.53 (d, $J_{3,4}$ $3.6 \mathrm{~Hz}, 1 \mathrm{H}, \mathrm{H}-4), 5.61$ (d, $\left.J_{1,2} 1.8 \mathrm{~Hz}, 1 \mathrm{H}, \mathrm{H}-1\right), 6.87$ (m, 2H, Ar-H), 
$7.04(\mathrm{~m}, 2 \mathrm{H}, \mathrm{Ar}-\mathrm{H}), 7.47-8.08(\mathrm{~m}, 5 \mathrm{H}, \mathrm{Bz}-\mathrm{H})$. Anal. Calcd for $\mathrm{C}_{20} \mathrm{H}_{22} \mathrm{O}_{7}: \mathrm{C}, 64.16 ; \mathrm{H}, 5.92$. Found: $\mathrm{C}, 63.90 ; \mathrm{H}, 6.20$.

\subsection{4-Methoxyphenyl 6-deoxy-4-0-pivaloyl- $\alpha$-L-talopyranoside} (5)

To a soln of 3 (6.2 g, $20 \mathrm{mmol})$ with DMAP $(1.0 \mathrm{~g}, 8.0 \mathrm{mmol})$ in pyridine $(30 \mathrm{~mL})$ was added pivaloyl chloride $(4.8 \mathrm{~mL}, 40 \mathrm{~mol})$ dropwise. After stirring for $2 \mathrm{~d}$ at $\mathrm{rt}$, TLC (3:1 petroleum etherEtOAc) indicated that the reaction was complete. $\mathrm{MeOH}(0.5 \mathrm{~mL})$ was added to the reaction mixture followed by stirring for $10 \mathrm{~min}$. Water $(100 \mathrm{~mL})$ was added and the aq soln was extracted with $\mathrm{CH}_{2} \mathrm{Cl}_{2}(3 \times 50 \mathrm{~mL})$, the extract was washed with $\mathrm{M} \mathrm{HCl}$ and satd aq sodium hydrogencarbonate, dried $\left(\mathrm{Na}_{2} \mathrm{SO}_{4}\right)$, and concentrated. The residue was dissolved in $70 \% \mathrm{AcOH}(200 \mathrm{~mL})$ and stirred for $3 \mathrm{~h}$ at $70^{\circ} \mathrm{C}$, at the end of which time TLC $(2: 1$ petroleum etherEtOAc) indicated that the reaction was complete. The mixture was concentrated and coevaporated with toluene $(2 \times 40 \mathrm{~mL})$. The residue was passed through a short silica-gel column with 5:2 petroleum ether-EtOAc as the eluent to give $\mathbf{5}(5.4 \mathrm{~g}, 76 \%$ for two steps) as a foamy solid; $[\alpha]_{\mathrm{D}}^{25}+44.5\left(\mathrm{c} 0.5 \mathrm{CHCl}_{3}\right) ;{ }^{1} \mathrm{H}$ NMR $(300 \mathrm{MHz}$, $\left.\mathrm{CDCl}_{3}\right): \delta 1.13\left(\mathrm{~d}, J_{5,6} 5.0 \mathrm{~Hz}, 3 \mathrm{H}, \mathrm{CH}_{3}\right), 1.30\left(\mathrm{~s}, 9 \mathrm{H},\left(\mathrm{CH}_{3}\right)_{3} \mathrm{CCO}\right)$, $2.56(\mathrm{~d}, J 11.3 \mathrm{~Hz}, 1 \mathrm{H}, \mathrm{OH}), 2.69(\mathrm{~d}, J 7.8 \mathrm{~Hz}, 1 \mathrm{H}, \mathrm{OH}), 3.78(\mathrm{~s}, 3 \mathrm{H}$, $\left.\mathrm{OCH}_{3}\right), 3.95(\mathrm{~m}, 1 \mathrm{H}, \mathrm{H}-2), 4.15-4.21(\mathrm{~m}, 2 \mathrm{H}, \mathrm{H}-3, \mathrm{H}-5), 5.25$ (d, $\left.J_{3,4} 3.7 \mathrm{~Hz}, 1 \mathrm{H}, \mathrm{H}-4\right), 5.58$ (d, $\left.J_{1,2} 1.5 \mathrm{~Hz}, 1 \mathrm{H}, \mathrm{H}-1\right), 6.82-6.86(\mathrm{~m}$, $2 \mathrm{H}, \mathrm{Ar}-\mathrm{H}), 6.96-7.02(\mathrm{~m}, 2 \mathrm{H}, \mathrm{Ar}-\mathrm{H})$. Anal. Calcd for $\mathrm{C}_{18} \mathrm{H}_{26} \mathrm{O}_{7}$ : C, $61.00 ; \mathrm{H}, 7.39$. Found: C, 60.86; H, 7.22.

\subsection{General procedure for the preparation of compounds 6a-e and $7 a-d$}

Compound 4 or 5 ( $2 \mathrm{mmol}$ ), in a $100 \mathrm{~mL}$ round-bottomed flask, was dried under high vacuum for $4 \mathrm{~h}$, and then anhyd $\mathrm{CH}_{2} \mathrm{Cl}_{2}$ $(20 \mathrm{~mL})$, pyridine $(4.0 \mathrm{~mL}, 50 \mathrm{mmol})$ and, in the case of $6 \mathbf{f}$ and $7 \mathbf{d}$, catalytic amounts of DMAP (50 mg, $0.4 \mathrm{mmol}$ ) were successively added to the flask under $\mathrm{N}_{2}$ atmosphere. The flask was cooled to $-15^{\circ} \mathrm{C}$ in an ice-salt-acetone bath and a soln of acyl chloride $(2.2 \mathrm{mmol})$ in dry $\mathrm{CH}_{2} \mathrm{Cl}_{2}(10 \mathrm{~mL})$ was added dropwise within $40 \mathrm{~min}$. The reaction mixture was slowly warmed to rt and stirred for a further $2 \mathrm{~h}$, at the end of which time TLC (3:1 petroleum ether-EtOAc) indicated the completion of the reaction. Water $(20 \mathrm{~mL})$ was added to the reaction mixture. The aq soln was extracted with $\mathrm{CH}_{2} \mathrm{Cl}_{2}(3 \times 20 \mathrm{~mL})$, the extract was washed with $\mathrm{M}$ $\mathrm{HCl}$ and satd aq sodium hydrogencarbonate, dried $\left(\mathrm{Na}_{2} \mathrm{SO}_{4}\right)$, and concentrated. The residue was subjected to silica-gel column chromatography (3:1-6:1 petroleum ether-EtOAc) to give the desired products $\mathbf{6 a - f}$ and $\mathbf{7 a - d}$ in high yields.

Analytical data for compounds $\mathbf{6 a - f}$ and $7 \mathbf{a}-\mathbf{d}$ are enclosed in Supplementary data.

\subsection{3-0-Allyloxycarbonyl-2,4-di- 0 -benzoyl- $\alpha-\mathrm{L}-$ rhamnopyranosyl trichloroacetimidate $(9)$}

To a soln of 4-methoxyphenyl 3-O-allyloxycarbonyl-2,4-di-Obenzoyl- $\alpha$-L-rhamnopyranoside $(8)^{21}(8.43 \mathrm{~g}, 0.015 \mathrm{~mol})$ in $80 \%$ $\mathrm{MeCN}(400 \mathrm{~mL})$ at $35^{\circ} \mathrm{C}$ was added CAN $(34.1 \mathrm{~g}, 0.06 \mathrm{~mol})$. The mixture was stirred at $35^{\circ} \mathrm{C}$ for $0.5 \mathrm{~h}$ while TLC (4:1 petroleum ether-EtOAc) indicated the completion of the reaction. The solvent was evaporated under diminished pressure at $50{ }^{\circ} \mathrm{C}$ to give a residue, which was dissolved in $\mathrm{CH}_{2} \mathrm{Cl}_{2}$, and washed with water. The organic phase was dried $\left(\mathrm{Na}_{2} \mathrm{SO}_{4}\right)$, concentrated, and then purified by silica-gel column chromatography with $3: 1$ petroleum etherEtOAc as the eluent to give 3-O-allyloxycarbonyl-2,4-di-O-benzoyl- $\alpha$-L-rhamnopyranose $(5.34 \mathrm{~g}, 78 \%$ ) as a yellow foam. A mixture of this compound $(5.34 \mathrm{~g}, 11.7 \mathrm{mmol})$, trichloroacetonitrile (4.0 $\mathrm{mL}, 40 \mathrm{mmol}$ ), and 1,8-diazabicyclo[5.4.0] undecene (DBU)
(0.30 mL, $30 \mathrm{mmol})$ in dry $\mathrm{CH}_{2} \mathrm{Cl}_{2}(40 \mathrm{~mL})$ was stirred until completion of the reaction (TLC, 3:1 petroleum ether-EtOAc). Concentration and purification of the residue by flash chromatography (6:1 petroleum ether-EtOAc) gave $\mathbf{9}(6.26 \mathrm{~g}, 89 \%)$ as a white foamy solid; $[\alpha]_{\mathrm{D}}^{25}+60.0\left(\right.$ c $\left.1.0 \mathrm{CHCl}_{3}\right) ;{ }^{1} \mathrm{H} \mathrm{NMR}\left(300 \mathrm{MHz}, \mathrm{CDCl}_{3}\right): \delta 1.39(\mathrm{~d}$, $\left.J_{5,6} 6.2 \mathrm{~Hz}, 3 \mathrm{H}, \mathrm{CH}_{3}\right), 4.30(\mathrm{~m}, 1 \mathrm{H}, \mathrm{H}-5), 4.49-4.51(\mathrm{~m}, 2 \mathrm{H}$, $\left.\mathrm{OCH}_{2} \mathrm{CH}=\mathrm{CH}_{2}\right), 5.02-5.18\left(\mathrm{~m}, 2 \mathrm{H}, \mathrm{OCH}_{2} \mathrm{CH}=\mathrm{CH}_{2}\right), 5.52-5.72(\mathrm{~m}$, $\left.3 \mathrm{H}, \mathrm{OCH}_{2} \mathrm{CH}=\mathrm{CH}_{2}, \mathrm{H}-3, \mathrm{H}-4\right), 5.82\left(\mathrm{dd}, J_{1,2} 2.0 \mathrm{~Hz}, J_{2,3} 3.2 \mathrm{~Hz}, 1 \mathrm{H}\right.$, $\mathrm{H}-2$ ), 6.44 (d, $J_{1,2} 2.0 \mathrm{~Hz}, \mathrm{H}-1$ ), 7.44-7.62 (m, 6H, Ar-H), 8.04-8.14 $(\mathrm{m}, 4 \mathrm{H}, \mathrm{Ar}-\mathrm{H}), 8.81\left(\mathrm{~s}, 1 \mathrm{H}, \mathrm{CNHCCl}_{3}\right)$. Anal. Calcd for $\mathrm{C}_{26} \mathrm{H}_{24} \mathrm{Cl}_{3} \mathrm{NO}_{9}$ : C, 51.97; H, 4.03; N, 2.33. Found: C, 51.82; H, 4.34; N, 2.72.

\subsection{4-Methoxyphenyl 3-O-allyloxycarbonyl-2,4-di-O-benzoyl- $\alpha$-L-rhamnopyranosyl-( $1 \rightarrow 2)$-3,4-di-0-benzoyl-6-deoxy-L- talopyranoside (10)}

To a cooled soln $\left(-10^{\circ} \mathrm{C}\right)$ of $\mathbf{9}(3.99 \mathrm{~g}, 6.6 \mathrm{mmol})$ and $\mathbf{6 c}(2.65 \mathrm{~g}$, $5.5 \mathrm{mmol})$ in anhyd $\mathrm{CH}_{2} \mathrm{Cl}_{2}(45 \mathrm{~mL})$ was added TMSOTf $(25 \mu \mathrm{L}$, $0.14 \mathrm{mmol}$ ). The mixture was stirred at this temperature for $2 \mathrm{~h}$, and then quenched with $\mathrm{Et}_{3} \mathrm{~N}$ ( 2 drops). The solvents were evaporated under diminished pressure to give a residue, which was purified by silica-gel column chromatography $(5: 1$ petroleum etherEtOAc) to give disaccharide $\mathbf{1 0}(4.43 \mathrm{~g}, 88 \%)$ as a foamy solid; $[\alpha]_{\mathrm{D}}^{25}-28.0$ (c $\left.1.0 \mathrm{CHCl}_{3}\right) ;{ }^{1} \mathrm{H}$ NMR $\left(300 \mathrm{MHz}, \mathrm{CDCl}_{3}\right): \delta 1.26(\mathrm{~d}, J$ $\left.5.6 \mathrm{~Hz}, 3 \mathrm{H}, \mathrm{CH}_{3}\right), 1.33$ (d, J $\left.5.9 \mathrm{~Hz}, 3 \mathrm{H}, \mathrm{CH}_{3}\right), 3.80\left(\mathrm{~s}, 3 \mathrm{H}, \mathrm{OCH}_{3}\right)$, 4.23-4.32 (m, $2 \mathrm{H}), 4.47-4.49\left(\mathrm{~m}, 3 \mathrm{H}, \mathrm{H}-2, \mathrm{OCH}_{2} \mathrm{CH}=\mathrm{CH}_{2}\right), 5.03-$ $5.19\left(\mathrm{~m}, 2 \mathrm{H}, \mathrm{OCH}_{2} \mathrm{CH}=\mathrm{CH}_{2}\right), 5.26(\mathrm{~s}, 1 \mathrm{H}), 5.50-5.56(\mathrm{~m}, 2 \mathrm{H})$, 5.64-5.76 (m, 4H), $5.87\left(\mathrm{dd}, J_{2,3}=J_{3,4}=3.6 \mathrm{~Hz}, 1 \mathrm{H}, \mathrm{H}-3\right), 6.88-6.91$ (m, 2H, Ar-H), 7.09-7.12 (m, 2H, Ar-H), 7.31-7.64 (m, 12H, Bz-H), 7.96-8.20 (m, 8H, Bz-H); ${ }^{13} \mathrm{C}$ NMR $\left(300 \mathrm{MHz}, \mathrm{CDCl}_{3}\right) \delta 16.3,17.6$, 55.7, 65.9, 67.6, 67.9, 68.7, 69.2, 70.1, 71.9, 72.4, 72.7, 98.7 (C-1), 99.1 (C-1), 114.8, 117.5, 118.8, 128.4, 128.4, 128.5, 128.6, 129.2, 129.2, 129.3, 129.8, 129.9, 130.1, 131.2, 133.0, 1332, 133.3, 133.5, $150.1,153.9,155.2,164.8,165.5,165.6,166.4$. Anal. Calcd for $\mathrm{C}_{51} \mathrm{H}_{48} \mathrm{O}_{16}$ : C, 66.80; H, 5.28. Found: C, 66.67; H, 5.39.

\subsection{4-Methoxyphenyl 2,4-di-O-benzoyl-L-rhamnopyranosyl- $(1 \rightarrow$ 2)-3,4-di-O-benzoyl-6-deoxy-L-talopyranoside (11)}

To a soln of 10 (1.28 g, $1.4 \mathrm{mmol})$ and $\mathrm{Et}_{3} \mathrm{~N}(0.38 \mathrm{~mL}, 2.8 \mathrm{mmol})$ in THF $(15 \mathrm{~mL})$ was added $\mathrm{PPh}_{3}(110 \mathrm{mg}, 0.42 \mathrm{mmol})$ and $\operatorname{Pd}\left[\mathrm{P}\left(\mathrm{C}_{6} \mathrm{H}_{5}\right)_{3}\right]_{4}(81 \mathrm{mg}, 0.07 \mathrm{mmol})$, and the mixture was stirred at $25{ }^{\circ} \mathrm{C}$ until TLC (3:1 petroleum ether-EtOAc) indicated completion of the reaction. The reaction mixture was concentrated under diminished pressure, and the residue was purified by flash chromatography on a silica-gel column (4:1 petroleum ether-EtOAc) to give $11(0.94 \mathrm{~g}, 81 \%)$ as a white solid; $[\alpha]_{\mathrm{D}}^{25}-32.0\left(\right.$ c $\left.0.5 \mathrm{CHCl}_{3}\right)$; ${ }^{1} \mathrm{H}$ NMR (300 MHz, $\mathrm{CDCl}_{3}$ ); $\delta 1.31$ (d, J $4.3 \mathrm{~Hz}, 3 \mathrm{H}, \mathrm{CH}_{3}$ ), 1.33 (d, J $\left.4.6 \mathrm{~Hz}, 3 \mathrm{H}, \mathrm{CH}_{3}\right), 2.07(\mathrm{~d}, J 6.6 \mathrm{~Hz}, 1 \mathrm{H}, \mathrm{OH}$, exchangeable with $\left.\mathrm{D}_{2} \mathrm{O}\right), 3.80\left(\mathrm{~s}, 3 \mathrm{H}, \mathrm{OCH}_{3}\right), 4.28-4.33(\mathrm{~m}, 2 \mathrm{H}), 4.49-4.51(\mathrm{~m}, 2 \mathrm{H})$, 5.19 (s, 1H, H-1), 5.26-5.35 (m, 2H), 5.69 (s, 1H, H-1), 5.70 (m, $1 \mathrm{H}), 5.82\left(\mathrm{dd}, J_{2,3}=J_{3,4}=3.6 \mathrm{~Hz}, 1 \mathrm{H}, \mathrm{H}-3\right), 6.88-6.91(\mathrm{~m}, 2 \mathrm{H}, \mathrm{Ar}-$ H), 7.08-7.11 (m, 2H, Ar-H), 7.35-7.64 (m, $12 \mathrm{H}, \mathrm{Bz}-\mathrm{H}), 7.98-8.20$ (m, 8H, Bz-H). Anal. Calcd for $\mathrm{C}_{47} \mathrm{H}_{44} \mathrm{O}_{14}: \mathrm{C}, 67.78 ; \mathrm{H}, 5.33$. Found: C, 67.70; H, 5.60.

\subsection{4-Methoxyphenyl 2,3,4-tri-O-benzoyl-L- rhamnopyranosyl-( $\rightarrow 3)$-2,4-di-O-benzoyl-L- rhamnopyranosyl- $(1 \rightarrow 3)-2,4-d i-O$-benzoyl-L- rhamnopyranosyl-( $1 \rightarrow 2)-3,4-d i-O$-benzoyl-6- deoxy-L-talopyranoside (13)}

To a cooled soln $\left(-10^{\circ} \mathrm{C}\right)$ of $\mathbf{1 1}(400 \mathrm{mg}, 0.48 \mathrm{mmol})$ and $\mathbf{1 2}^{22}$ (500 $\mathrm{mg}, 0.53 \mathrm{mmol}$ ) in anhyd $\mathrm{CH}_{2} \mathrm{Cl}_{2}(25 \mathrm{~mL}$ ) was added TMSOTf ( $25 \mu \mathrm{L}, 0.14 \mathrm{mmol}$ ). The mixture was stirred at this temperature for $2 \mathrm{~h}$, and then quenched with $\mathrm{Et}_{3} \mathrm{~N}$ (2 drops). The solvent was 
evaporated under diminished pressure to give a residue, which was purified by silica-gel column chromatography (3:1 petroleum ether-EtOAc) to give the tetrasaccharide $13(600 \mathrm{mg}, 76 \%)$ as a foamy solid; $[\alpha]_{\mathrm{D}}^{25}+78\left(\right.$ c $\left.1.0 \mathrm{CHCl}_{3}\right) ;{ }^{1} \mathrm{H} \mathrm{NMR}\left(600 \mathrm{MHz}, \mathrm{CDCl}_{3}\right): \delta 0.79$ $\left(\mathrm{d}, J 6.6 \mathrm{~Hz}, 3 \mathrm{H}, \mathrm{CH}_{3}\right), 0.80\left(\mathrm{~d}, J 6.6 \mathrm{~Hz}, 3 \mathrm{H}, \mathrm{CH}_{3}\right), 1.31(\mathrm{~d}, J 6.6 \mathrm{~Hz}, 3 \mathrm{H}$, $\left.\mathrm{CH}_{3}\right), 1.34\left(\mathrm{~d}, \mathrm{~J} 6.3 \mathrm{~Hz}, 3 \mathrm{H}, \mathrm{CH}_{3}\right), 3.74-3.76\left(\mathrm{~m}, 1 \mathrm{H}, \mathrm{H}-5^{\prime}\right), 3.79(\mathrm{~s}, 3 \mathrm{H}$, $\left.\mathrm{OCH}_{3}\right), 3.81\left(\mathrm{~m}, 1 \mathrm{H}, \mathrm{H}-5^{\prime \prime}\right), 4.18$ (dd, $J_{2,3} 3.0 \mathrm{~Hz}, J_{3,4} 9.6 \mathrm{~Hz}, 1 \mathrm{H}, \mathrm{H}-3^{\prime}$ ), 4.29 (dd, $J_{1,2} 1.2 \mathrm{~Hz}, J_{2,3} 3.6 \mathrm{~Hz}, 1 \mathrm{H}, \mathrm{H}-2$ ), $4.30-4.33$ (m, $1 \mathrm{H}, \mathrm{H}-5^{\prime \prime \prime}$ ), 4.38 (dd, $J_{2,3} 3.0 \mathrm{~Hz}, J_{3,4} 9.6 \mathrm{~Hz}, 1 \mathrm{H}, \mathrm{H}-3^{\prime \prime}$ ), 4.48 (q, $1 \mathrm{H}, \mathrm{H}-5$ ), 4.69 (d, $J_{1,2} 0.6 \mathrm{~Hz}, 1 \mathrm{H}, \mathrm{H}-1^{\prime}$ ), 4.84 (d, $\left.J_{1,2} 1.2 \mathrm{~Hz}, 1 \mathrm{H}, \mathrm{H}-1^{\prime \prime \prime}\right), 5.13$ (dd, $J_{1,2} 0.6$, $\left.J_{2,3} 3.0 \mathrm{~Hz}, 1 \mathrm{H}, \mathrm{H}-2^{\prime}\right), 5.17$ (dd, $\left.J_{1,2} 1.2 \mathrm{~Hz}, J_{2,3} 3.0 \mathrm{~Hz}, 1 \mathrm{H}, \mathrm{H}-2^{\prime \prime \prime}\right), 5.29$ (d, $J_{1,2} 1.8 \mathrm{~Hz}, 1 \mathrm{H}, \mathrm{H}-1^{\prime \prime}$ ), 5.30 (dd, $J_{3,4}=J_{4,5}=9.6 \mathrm{~Hz}, 1 \mathrm{H}, \mathrm{H}-4^{\prime}$ ), 5.35 (dd, $J_{3,4}=J_{4,5}=9.6 \mathrm{~Hz}, 1 \mathrm{H}, \mathrm{H}-4^{\prime \prime \prime}$ ), $5.46\left(\mathrm{dd}, J_{2,3} 3.0 \mathrm{~Hz}, J_{3,4} 9.6 \mathrm{~Hz}\right.$, $\left.1 \mathrm{H}, \mathrm{H}-3^{\prime \prime \prime}\right), 5.50$ (dd, $J_{1,2} 1.8 \mathrm{~Hz}, J_{2,3} 3.0 \mathrm{~Hz}, 1 \mathrm{H}, \mathrm{H}-2^{\prime \prime}$ ), 5.55 (dd, $\left.J_{3,4}=J_{4,5}=9.6 \mathrm{~Hz}, 1 \mathrm{H}, \mathrm{H}-4^{\prime \prime}\right), 5.66\left(\mathrm{~d}, J_{3,4} 3.6 \mathrm{~Hz}, 1 \mathrm{H}, \mathrm{H}-4\right), 5.75(\mathrm{~d}$, $\left.J_{1,2} 1.2 \mathrm{~Hz}, 1 \mathrm{H}, \mathrm{H}-1\right), 5.83\left(\mathrm{dd}, J_{2,3}=J_{3,4}=3.6 \mathrm{~Hz}, 1 \mathrm{H}, \mathrm{H}-3\right.$ ), 6.86$7.24(\mathrm{~m}, 7 \mathrm{H}), 7.27-7.75(\mathrm{~m}, 32 \mathrm{H}), 8.10-8.14(\mathrm{~m}, 10 \mathrm{H}) ;{ }^{13} \mathrm{C} \mathrm{NMR}$ $\left(300 \mathrm{MHz}, \mathrm{CDCl}_{3}\right) ; \delta 16.4,16.9,17.3,17.8,98.6(\mathrm{C}-1), 99.0$ (C-1), 99.0 (C-1), 99.8 (C-1), 164.7, 165.4, 165.5, 165.5, 165.5, 165.7, 166.1, 166.3, 167.1 (9 BzCO). Anal. Calcd for $\mathrm{C}_{94} \mathrm{H}_{84} \mathrm{O}_{27}$ : C, 68.61; H, 5.14. Found: C, 68.89; H, 5.30.

\subsection{4-Methoxyphenyl L-rhamnopyranosyl- $(1 \rightarrow 3)-\mathrm{L}-$ rhamnopyranosyl- $(1 \rightarrow 3)$-L-rhamnopyranosyl- $(1 \rightarrow 2)-6$ - deoxy-L-talopyranoside (II)}

Tetrasaccharide 13 (200 mg, $0.12 \mathrm{mmol}$ ) was dissolved in satd $\mathrm{NH}_{3}-\mathrm{MeOH}$ (30 mL). After $96 \mathrm{~h}$ at $\mathrm{rt}$, the reaction mixture was concentrated, and the residue was purified by chromatography on Sephadex LH-20 (MeOH) to afford II (77 mg, 91\%) as a foamy solid; $[\alpha]_{\mathrm{D}}^{25}+55.8\left(c 0.5 \mathrm{H}_{2} \mathrm{O}\right) ;{ }^{1} \mathrm{H}$ NMR $\left(300 \mathrm{MHz}, \mathrm{D}_{2} \mathrm{O}\right): \delta 1.09-1.40(\mathrm{~m}$, $12 \mathrm{H}), 3.23-3.49(\mathrm{~m}, 4 \mathrm{H}), 3.66-3.81(\mathrm{~m}, 12 \mathrm{H}), 3.96-4.09(\mathrm{~m}, 7 \mathrm{H})$, 4.93 (s, 3H, $3 \mathrm{H}-1), 5.41$ (s, $1 \mathrm{H}, \mathrm{H}-1), 6.84-6.97$ (m, $4 \mathrm{H}, \mathrm{Ar}-\mathrm{H}) ;{ }^{13} \mathrm{C}$ $\operatorname{NMR}\left(300 \mathrm{MHz}, \mathrm{D}_{2} \mathrm{O}\right.$ ): $\delta$ 15.4, 16.6, 16.7, 16.7 (4 Me), 25.0 (OMe), 98.9, 102.2, 102.5, 102.6 (4 C-1); MALDI-TOFMS: $\mathrm{m} / \mathrm{z} 731.5$ $\left[\mathrm{M}+\mathrm{Na}^{+}\right]$; HRESIMS: calcd for $\left[\mathrm{C}_{31} \mathrm{H}_{48} \mathrm{O}_{18}\right] \mathrm{Na}^{+}$: 731.2735 , found: $m / z 731.2733$.

\section{Acknowledgments}

This work was supported by the Scientific Research Foundation for the Returned Overseas Chinese Scholars, State Education
Ministry (No.: 21168020) and the Doctoral Program Foundation of Institutions of Higher Education of China (No.: 20070019072).

\section{Supplementary data}

Supplementary data associated with this article can be found, in the online version, at doi:10.1016/j.carres.2008.09.010.

\section{References}

1. Chatterjee, D.; Bozic, C.; Aspinall, G. O.; Brennan, P. J. J. Biol. Chem. 1988, 263, 4092-4097.

2. Aspinall, G. O.; Crane, A. M.; Gammon, D. W.; Ibrahim, I. H.; Khare, N. K.; Chatterjee, D.; Rivoire, B.; Brennan, P. J. Carbohydr. Res. 1991, 216, 337355.

3. Aspinall, G. O.; Khare, N. K.; Sood, R. K.; Chatterjee, D.; Rivoire, B.; Brennan, P. J. Carbohydr. Res. 1991, 216, 357-373.

4. Daubenspeck, J. M.; Zeng, H.; Chen, P.; Dong, S.; Steichen, C. T.; Krishna, N. R.; Pritchard, D. G.; Turnbough, C. L. J. Biol. Chem. 2004, 279, 30945-30953.

5. Zahringer, U.; Rettenmaier, H.; Moll, H.; Senchenkova, S. N.; Knirel, Y. A. Carbohydr. Res. 1997, 300, 143-151.

6. Forsberg, L. S.; Bhat, U. R.; Carlson, R. W. J. Biol. Chem. 2000, 275, 1885118863.

7. Zatonsky, G. V.; Kocharova, N. A.; Veremeychenko, S. P.; Zdorovenko, E. L.; Shashkov, A. S.; Zdorovenko, G. M.; Knirel, Y. A. Carbohydr. Res. 2002, 337, 2365-2370.

8. Castro, C. D.; Gargiulo, V.; Lanzetta, R.; Parrilli, M. Biomacromolecules 2007, 8, 1047-1051.

9. Turska-Szewczuk, A.; Palusinska-Szysz, M.; Russa, R. Carbohydr. Res. 2008, 343, 477-482.

10. Fujiwara, N.; Nakata, N.; Maeda, S.; Naka, T.; Doe, M.; Yano, I.; Kobayashi, K. J. Bacteriol. 2007, 189, 1099-1108.

11. Chatterjee, D.; Khoo, K. H. Cell Mol. Life Sci. 2001, 58, 2018-2042.

12. Liptak, A.; Kerekgyarto, J.; Popsavin, V.; Kajtar-Peredy, M.; Radies, L. J. Carbohydr. Chem. 1988, 7, 337-357.

13. Zuurmond, H. M.; Veeneman, G. H.; Mare1, G. A.; Boom, J. H. Carbohydr. Res. 1993, 241, 153-164.

14. Heidelberg, T.; Martin, O. R. J. Org. Chem. 2004, 69, 2290-2301.

15. Fekete, A.; Gyergyoi, K.; Kover, K. E.; Bajza, I.; Liptak, A. Carbohydr. Res. 2006, 341, 1312-1321.

16. Sarkar, K.; Mukherjee, I.; Roy, N. J. Carbohydr. Chem. 2003, 22, 95-107.

17. Czernecki, S.; Georgoulis, C.; Stevens, C. L.; Vijayakumaran, K. Tetrahedron Lett. 1985, 26, 1699-1702.

18. Gan, Z.; Kong, F. Carbohydr. Res. 1995, 270, 211-216.

19. Gurjar, M. K.; Viswanadham, G. Tetrahedron Lett. 1991, 32, 6191-6194.

20. Aspinall, G. O.; Takeo, K. Carbohydr. Res. 1983, 121, 61-77.

21. Zhang, J.; Zong, G.; Liang, X.; Li, Y.; Wang, D.; Kong, F. Chin. Chem. Lett. 2008, 19, 415-418.

22. Zhang, J.; Ning, J.; Kong, F. Carbohydr. Res. 2003, 338, 1023-1031.

23. Schmidt, R. R. Angew. Chem., Int. Ed. Engl. 1986, 25, 212-235.

24. Hayakawa, Y.; Kato, H.; Uchiyama, M.; Kajino, H.; Noyori, R. J. Org. Chem. 1986, 51, 2400-2402. 